\title{
TFG/ALK Short Form Fusion Protein
}

National Cancer Institute

\section{Source}

National Cancer Institute. TFG/ALK Short Form Fusion Protein. NCI Thesaurus. Code C101080.

A fusion protein (701 aa, 78 kDa) encoded by the TFG/ALK short form fusion gene. This protein is comprised of about one third of the $\mathrm{N}$-terminal sequence of protein TFG, including the coiled-coil oligomerization domain, fused to the cytoplasmic domain of the ALK tyrosine kinase receptor protein. 